\title{
AN ANALYSIS ON RECORD POLITENESS OF PRAGMATIC IN TINKER BELL AND THE GREAT FAIRY RESCUE MOVIE
}

\author{
Pipit Aulia $^{1}$, Rani Marliani², Lilis Suryani ${ }^{3}$ \\ ${ }^{1}$ IKIP Siliwangi \\ ${ }^{2}$ IKIP Siliwangi \\ ${ }^{3}$ IKIP Siliwangi \\ ${ }^{1}$ kupitpipitaulia@gmail.com, ${ }^{2}$ raniendog15@gmail.com, ${ }^{3}$ suryani.lies3@gmail.com
}

\begin{abstract}
This research is a linguistic study on record politeness of pragmatic in tinker bell and great fairy rescue movie, which aims to know many types of politeness and the most dominant politeness in the film. Researchers use qualitative method and the data are analyzed based on the politeness theory by Brown and Lavinson (1987). The movie lasted 1 hour 25 minutes, including 30 conversation. The result showed that there are four politeness, they are conversation bald on record (16), positive politeness (8), negative politeness (2), and off record (2). In addition the most of dominant politeness is bald on record. It means that the bald on record is an order that is directly when a someone do something in urgent situation
\end{abstract}

Keywords: Politeness, Pragmatic, On record

\section{INTRODUCTION}

People communicate with other people and they use their own politeness. Pragmatic is a subfield of linguistics which studies how people comprehend and produce a communicative act or speech act in a concrete speech situation which is usually in the form of utterance. Pragmatic is the study of the aspect of meaning and language use that is dependent on the speaker, the addressee and the other features of the context of utterance. Kurniatin (2017) states that pragmatics deal with the study of the ability of natural language speaking to communicate more than one language that which is explicitly stated. In the philosophy of language, a natural language or sometimes called ordinary language is a language which is spoken, written, or signed by human beings for the general purpose of communication.

With the different term pragmatics is a about the relationship of our semantic knowledge with our knowledge of the world, taking into account context of use (Griffith,(2006: 1). In addition, Yule (1996) cited in (Septyaningsih, 2007) also describes pragmatics as the study of the speaker meaning. This types and how the context influences what is said. It requires a consideration of how speakers organize what they want to say in accordance with who they are talking to, where, when and under what circumstances. Pragmatics is the study of contextual meaning. From the explanation of pragmatics given, pragmatics is a study about language, meaning, and the context in communication.

Politeness is a universal and best expressed as the practical application of good manners or etiquette. Leech (1993) cited as in Manik \& Hutagaol (2015) defines it as "strategic conflict avoidance, which can be measured in terms of the degree of effort and put into the avoidance of conflict, situation, maintenance and establishment of comity. The avoidance is represented as a conscious effort on part of the person to be polite. Politeness strategies are more likely to be used when a speaker of relatively lower power makes a larger request in a more distant 
relationship than when a speaker of relatively higher power makes a smaller request in a closer relationship Brown \& Levinson (1987) cited in (Manik \& Hutagaol, 2015) Politeness strategies are ways to convey the speech acts as polite as possible. Beside that Hill, Ide, and Ikuta (1986) cited in Septiyani, 2016) define politeness as "one of the constraints on human interaction, whose purpose is to consider others feelings, to establish levels of mutual comfort and to promote rapport." Politeness, however, it has little to do with good manners, such as saying "please" or "sorry". It means that Politeness is always attributed to rules speak, In the politness one should be able to put on a certain situation where to respect each other

According to Brown and Levinson (1987) cited in Norra (2015), there are four main types of politeness strategies: bald on record, negative politeness, positive politeness and off-record (indirect)

\section{Bald On-Record}

This strategy is tends to show an urgent situation, emphasize maximum efficiency, noncooperation from the hearer, the speaker cares about the hearer, granting permission for the hearer and even imperative.

2.Positive politeness

In this strategy is oriented to enhance the positive face or hearer .positive face of the hearer. Positive face is the hearer needs to be appreciated and accepted by bothering it leads to achieving solidarity through offers of friendship.

3.Negative politeness

This strategy is tends to show be conventionally indirect, to show deference, emphasize the importance of others time or concerns, an apology for interruption, impersonalize $\mathrm{S}$ and $\mathrm{H}$, state the FTA as a general rule and even includes nominalize.

4.Off-record indirect strategy

The strategy of off record can be performed such strategy 1: give hints 2: give association clues 3: purpose 4: understate 5.overstate 6: use tautologies 7: use contradictions 8: be ironic 9: use metaphors 10: theoretical question 11: be ambiguous 12: be vague 13: over generalize 15: be incomplete use ellipsis . It can be concluded is politeness is an act in which a person expresses or declare a language with a smooth (polite).

Researchers analyzed the film footage of Tinker Bell and the Great Fairy Rescue Movie because the film had an interesting story and can be watched by all ages. Tinker Bell and Great Fairy Rescue is a computer-animated film based on the Disney Fairies franchise, produced by Margot Pipkin, directed by Bradley Raymond. And the duration of the film is 1 hour 25 minutes with English. The Film is produced using digital 3D modeling. The Album was released on DVD and Blu-Ray by Walt Disney Studios Home Entertainment on September 21, 2010.

In addition Krisnoni (2013) shows that the greatest number of politeness strategies are used by all bald characters - on records that are 72 cases. Based on the explanation above the researchers, would like to know the types of politeness and the most dominant politeness in tinker bell movie.

\section{METHOD}

In this research, the researchers used a qualitative research method. Qualitative research is investigated about how to social word interpreted, understood, experienced or produced based on methods of analysis and explanation building which involve understandings of complexity, detail and context (Hughes, 2003). Supported by Suryani,L \& Argawati (2018) that qualitative is the result of the resears in the form of description. The researchers used document analysis for collecting the data of pragmatic in tinker bell and the great fairy rescue movie. While for the 
analysis of the data, there are some steps in analyzing the data. First, listening and watching the Tinker Bell and The Great Fairy Rescue movie. Second, analysis pragmatics in Tinker Bell and The Great Fairy Rescue movie based on Brown, P.,\& Levinson (1987)

\section{RESULTS AND DISCUSSION}

\section{Results}

The researchers analyzed the Tinker Bell and Great Fairy Rescue Movie that the duration 1 hour 25 minutes. The researchers found several conversations that included them on record. Then the researchers distribute where the sentences are included into bald on record, negative politeness, positive politeness and off record. Here is a result distributed by the researchers.

The text of the dialog:

\section{Bald On Record}

In the movie Tinker Bell many characters that used Bald on Record as much as 18 conversation. Bald on Record has the strategy Urgent situation, Maximum efficiency, Satisfying the hearer's face is smile Speaker cares about hearer and Imperative . In addition, (Brown, P.,\& Levinson, 1987) strategy as speaking in conformity with Grice's maxims, these maxims are intuitively the characterization of conversational principles that will constitute guidelines for achieving maximally efficient communication.

Exp: Close the door, please! / Go ahead

a. X: Come on, Tink. Let's go inside.

Y: Inside? (00:05.15)

b. X: Tinker Bell! Don't eat that! This could be a trap. (00:12:01)

Y: Come on, Vidia. It's perfectly safe.

c. X: I wonder what this part does. Tink! I'm serious! Get out of there! Just a second. Just a second. (00:18.15)

Y: Vidia? Vidia?

d. X: Oh Vidia, come on. Open the door. (00:56:10)

Y: You had your little...

e. X: Father!

Y: Lizzy, Please. (00:20:02)

f. X: Then we better leave right away! (00:39:23)

Y: Sil, do you think the storm will pass soon?

g. X: Come on let's going

Y: Let's get go $(00: 21.34)$

h. X: Got it! Clanky, rescue device. (01:10:32)

Y: Right, Bobble. You can count on us!

i. X: Clank! (01:17:06)

Y: Come on!

j. X: Vidia?

Y: Get out of the way! (01:07:53)

k. X: More mushroom caps, please! (00:22.02)

Y: This one goes there

1. X: Give me a sap. (00:22.30)

Y: You dip it in this way

m. X: Come on come on let's get going (00:22.55)

$\mathrm{Y}$ : There you go

n. X: Hello...

Y: You don't have to be scared (00:50:48) 
$(01: 12: 09)$

o. X: Come on, please, let them still be there.

Y: Father (01:02:04)

p. X: Please tell me you're not going in there! She went in there.

$\mathrm{Y}: \mathrm{Oh}$ !

2.Positive Politeness

In the movie Tinker Bell many character that used Positive Politeness as much as 8 conversation. Positive Politeness there are some strategy : asserting speaker knowledge of the concers for hearer's wants, including both speaker and hearer's in the activity. in addition (Brown, P.,\& Levinson, 1987) define positive politeness as "redress directed to the addressee positive face (the need to be connected)"

Exp: if you need to help, tell me about it.

a. X: Hey, Tink! You ready for your first summer on the mainland?

Y: Absolutely! It's so beautiful out here. (01:24:07)

b. X: Tink, fairy camp isn't out here in the open.

Y: We need to stay hidden from the humans. (00:13:01)

c. X: Like a dream Tink. Thanks Great. Need any help with that wagon?

Y: No, thanks. She's running fine. (00:45:33)

d. X: Would you like to come?

Y: Not now, Lizzy. (00:37:25)

e. X: Here, Vidia, let me help you.

Y: Tinker Bell, maybe if you spent less tme causing disasters, you wouldn't have to help everybody so much. (00:56:25)

f. X: I'm so sorry. Where are my manners? (01:02:19)

Y: There you go.

g. X: Lizzy?

Y: Why, hello, Father. May I help you? (00:48:23)

h. X: It's my pleasure, I'm sure. (01:03:30)

$\mathrm{Y}$ : Thank you.

3.Negative Politeness

In the movie Tinker Bell many character that used Negative Politeness as much as 2 conversation. Negative Politeness have there are several strategy is conventionally indirect, giving deferencen in Negative politeness, according to(Brown, P.,\& Levinson, 1987) is "resistive action addressed to the addressee negative face (the need to be independent and freedom from imposition).

Exp: Mrs neza, may I have a moment?

a. X: And I think what rotates the chain is this big...

Y: I don't care Tinker Bell. You shouldn't be this close to the human house. (00:59:01)

b. X: I am very disappointed to you (00:58:09)

Y: I am scared tinker bell

4.Off Record

In the movie Tinker Bell many character that used Off Record as much as 2 conversation. Support by Brown and Levinson adopted the Gricean frame work for categorize off-record strategies; hence, strategies can be grouped according to the specific maxim that is violated.

Exp: Oh god, i forgot to bring my research paper

a. X: There's a human house? (00:07:04)

Y: No! I mean, yes, but no.

b. X: Here's your house, little fairies.

Y: Whatever you are, hmm (00:15:25). 


\section{CONCLUSION}

Based on 30 on record the conversations we found that included meeting our meticulous criteria on the film, that are bald on record. Because bald on record is contextually addressed directly to a person, and they are deemed to have a good relationship, then bald on record conversation also get a dominant (16) good response as well. But however, positive politeness, negative politeness, and off record also exists in this movie, The researchers analysis on record of the movie. And for the further researchers can use another source which is more interesting to find more on record.

\section{ACKNOWLEDGMENTS}

In the name of Allah the most beneficial and the most merciful. All praises are to Allah SWT for all the blessing so that the writers can accomplish this article. The writers would like to express their genuine gratitude to :

1. Especially, Ms.Lilis suryani M.Pd as a supervisor, for her invaluable guidance, suggestion and feedback during the completion of this journal project

2. My parents who have been willing to my support system

3. Thank's to my partner everytime you're able to find some humor in a difficult situation.

\section{REFERENCES}

Brown, P.,\& Levinson, S. . (1987). Politeness: some universals in language usage (Second). Cambridge: Cambridge University Press.

Griffith, P. (2006). An Introduction to English Semantics and Pragmatics. Edinburgh: Edinburgh University Press Ltd.

Hughes, C. 2003. An Introduction to Qualitative Research.

Manik, S., \& Hutagaol, J. (2015). An Analysis on Teachers' Politeness Strategy and Student's Compliance in Teaching Learning Process at SD Negeri 024184 Binjai Timur Binjai North Sumatra-Indonesia. English Language Teaching, 8(8), 152-170. https://doi.org/10.5539/elt.v8n8p152

Norra, R. N. (2015). An Analysis of Politeness Strategies in Her Movie. State Islamic University Syrif Hidayatullah.

Nurzanah, S. (2012). An Analysis of Negative Politeness Strategy Used by Harry Potter in JK Rowling's Novel harry Potter and The Chamber of Secret.

Septiyani, W. (2016). The Use of Brown and Levinson's Politeness Strategies by The Main Characters of Bride Wars Movie.

Septyaningsih, A. (2007). An Analysis of Positive Politeness Strategy in The Film Entitled "In Good Company ” ( a pragmatics study). Sebelas Maret University.

Suryani,L \& Argawati, N. . (2018). The Implementation of lesson study to promote lecturer skill on teaching academic writing. Proseding Semnas. Retrieved from http://conference.ikipsiliwangi.ac.id 